\title{
Front Matter: Volume 7575
}

, "Front Matter: Volume 7575," Proc. SPIE 7575, Colloidal Quantum Dots for Biomedical Applications V, 757501 (19 March 2010); doi: 10.1117/12.855209

SPIE. Event: SPIE BiOS, 2010, San Francisco, California, United States 


\title{
Colloidal Quantum Dots for Biomedical Applications V
}

\author{
Marek Osiński \\ Wolfgang J. Parak \\ Thomas M. Jovin \\ Kenji Yamamoto \\ Editors
}

23-25 January 2010

San Francisco, California, United States

Sponsored

SPIE

Cosponsored by

Ocean Optics, Inc. (United States)

Published by

SPIE 
The papers included in this volume were part of the technical conference cited on the cover and title page. Papers were selected and subject to review by the editors and conference program committee. Some conference presentations may not be available for publication. The papers published in these proceedings reflect the work and thoughts of the authors and are published herein as submitted. The publisher is not responsible for the validity of the information or for any outcomes resulting from reliance thereon.

Please use the following format to cite material from this book:

Author(s), "Title of Paper," in Colloidal Quantum Dots for Biomedical Applications V, edited by Marek Osinski, Wolfgang J. Parak, Thomas M. Jovin, Kenji Yamamoto, Proceedings of SPIE Vol. 7575 (SPIE, Bellingham, WA, 2010) Article CID Number.

ISSN 1605-7422

ISBN 9780819479716

Published by

SPIE

P.O. Box 10, Bellingham, Washington 98227-0010 USA

Telephone +1 3606763290 (Pacific Time) · Fax +1 3606471445

SPIE.org

Copyright (@ 2010, Society of Photo-Optical Instrumentation Engineers.

Copying of material in this book for internal or personal use, or for the internal or personal use of specific clients, beyond the fair use provisions granted by the U.S. Copyright Law is authorized by SPIE subject to payment of copying fees. The Transactional Reporting Service base fee for this volume is $\$ 18.00$ per article (or portion thereof), which should be paid directly to the Copyright Clearance Center (CCC), 222 Rosewood Drive, Danvers, MA 01923. Payment may also be made electronically through CCC Online at copyright.com. Other copying for republication, resale, advertising or promotion, or any form of systematic or multiple reproduction of any material in this book is prohibited except with permission in writing from the publisher. The CCC fee code is 1605$7422 / 10 / \$ 18.00$.

Printed in the United States of America.

Publication of record for individual papers is online in the SPIE Digital Library.

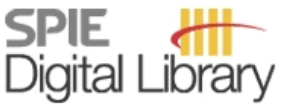

SPIEDigitalLibrary.org

Paper Numbering: Proceedings of SPIE follow an e-First publication model, with papers published first online and then in print and on CD-ROM. Papers are published as they are submitted and meet publication criteria. A unique, consistent, permanent citation identifier (CID) number is assigned to each article at the time of the first publication. Utilization of CIDs allows articles to be fully citable as soon they are published online, and connects the same identifier to all online, print, and electronic versions of the publication. SPIE uses a six-digit CID article numbering system in which:

- The first four digits correspond to the SPIE volume number.

- The last two digits indicate publication order within the volume using a Base 36 numbering system employing both numerals and letters. These two-number sets start with 00, 01, 02, 03, 04, $05,06,07,08,09,0 A, 0 B \ldots$. 0Z, followed by 10-1Z, 20-2Z, etc.

The CID number appears on each page of the manuscript. The complete citation is used on the first page, and an abbreviated version on subsequent pages. Numbers in the index correspond to the last two digits of the six-digit CID number. 


\section{Contents}

vii Conference Committee

SESSION 1 SYNTHESIS AND CHARACTERIZATION OF COLLOIDAL NANOCRYSTALS FOR BIOMEDICAL APPLICATIONS I

757504 Silica capped CdS/Cd(OH)2 quantum dots for biological applications [7575-04]

C. R. Chaves, Univ. Federal de Pernambuco (Brazil); D. B. Almeida, C. L. Cesar, Univ. Estadual de Campinas (Brazil); A. Fontes, B. S. Santos, P. M. A. Farias, Univ. Federal de Pernambuco (Brazil)

\section{SESSION 2 SYNTHESIS AND CHARACTERIZATION OF COLLOIDAL NANOCRYSTALS FOR BIOMEDICAL} APPLICATIONS II

757505 Light-controlled one-sided growth of large plasmonic gold domains on quantum rods observed on the single particle level (Invited Paper) [7575-05]

L. Carbone, A. Jakab, Y. Khalavka, C. Sönnichsen, Univ. of Mainz (Germany)

757506 Synthesis and surface modification of highly fluorescent gold nanoclusters and their exploitation for cellular labeling (Ocean Optics Young Investigator Award) [7575-06] C.-A. J. Lin, C.-H. Lee, J.-T. Hsieh, W.-C. Yu, H.-Z. Yang, Chung Yuan Christian Univ. (Taiwan) and Ctr. for Nano Bioengineering, Chung Yuan Christian Univ. (Taiwan); J. K. Li, National Univ. of Tainan (Taiwan); R. Sperling, Philipps-Univ. Marburg (Germany); H.-S. Wang, H.-I. Yeh, Mackay Memorial Hospital (Taiwan); W. J. Parak, Philipps-Univ. Marburg (Germany); W. H. Chang, Chung Yuan Christian Univ. (Taiwan) and Ctr. for Nano Bioengineering, Chung Yuan Christian Univ. (Taiwan)

757507 Biocompatible water soluble UV-blue-emitting ZnSe quantum dots for biomedical applications [7575-07]

J. J. Andrade, A. G. Brasil, Jr., B. J. A. P. Barbosa, C. A. Azevedo Filho, E. S. Leite, P. M. A. Farias, A. Fontes, B. S. Santos, Univ. Federal de Pernambuco (Brazil)

\section{SESSION 3 BIOFUNCTIONALIZATION OF COLLOIDAL NANOCRYSTALS}

75750 A Interactions between a colloidal CdTe quantum dot and distinct functionalizer compounds [7575-10]

E. S. Leite, Univ. Federal de Pernambuco (Brazil); J. Sousa, Federal Univ. of Ceará (Brazil); A. G. Brasil, Jr., K. H. G. Carvalho, A. Fontes, P. M. A. Farias, B. S. Santos, Univ. Federal de Pernambuco (Brazil) 
7575 OC Quantum dot-fluorescent protein pair as ratiometric pH sensor [7575-12]

A. M. Dennis, Georgia Institute of Technology (United States), Emory Univ. (United States), and Los Alamos National Lab. (United States); G. Bao, Georgia Institute of Technology (United States) and Emory Univ. (United States)

7575 OD Energy transfer from terbium complexes to quantum dots: the advantage of independent donor and acceptor decay time analysis for investigations on FRET distance dependence [7575-13]

N. Hildebrandt, NanoPolyPhotonics, Fraunhofer Institute for Applied Polymer Research (Germany)

7575 OE Optical size determination of quantum dots using FRET with terbium complexes as donors [7575-14]

D. Geißler, H.-G. Löhmannsröben, Univ. Potsdam (Germany); L. J. Charbonnière, Lab. d'Ingénierie Moléculaire Analytique, CNRS, Univ. Louis Pasteur (France); R. F. Ziessel, Lab. de Chimie Organique et Spectroscopie Avancée, CNRS, Univ. Lovis Pasteur (France); N. G. Butlin, Lumiphore Inc. (United States); I. L. Medintz, U.S. Naval Research Lab. (United States); H. Mattoussi, Florida State Univ. (United States); N. Hildebrandt, NanoPolyPhotonics, Fraunhofer Institute for Applied Polymer Research (Germany)

SESSION 5

NOVEL QUANTUM-DOT-BASED SENSORS

7575 OF Immobilization of quantum dots in multiple responsive microgels for biomedical applications (Invited Paper) [7575-15]

W. Wu, T. Zhou, M. Aiello, S. Zhou, The Ctr. for Engineered Polymeric Materials, College of Staten Island (United States) and The Graduate Ctr., CUNY (United States)

$7575 \mathrm{OH}$ Whispering-gallery-mode-based biosensing using quantum dot-embedded microspheres [7575-17]

H. T. Beier, G. L. Coté, K. E. Meissner, Texas A\&M Univ. (United States)

$75750 \mathrm{~J}$ Three-dimensional single molecule tracking of quantum-dot labeled antibody molecules using multifocal plane microscopy (Invited Paper) [7575-19]

S. Ram, The Univ. of Texas Southwestern Medical Ctr. at Dallas (United States); P. Prabhat, J. Chao, The Univ. of Texas Southwestern Medical Ctr. at Dallas (United States) and The Univ. of Texas at Dallas (United States); E. S. Ward, The Univ. of Texas Southwestern Medical Ctr. at Dallas (United States); R. J. Ober, The Univ. of Texas Southwestern Medical Ctr. at Dallas (United States) and The Univ. of Texas at Dallas (United States)

7575 OK Synthesis and manipulation of multifunctional, fluorescent-magnetic nanoparticles for single molecule tracking [7575-20]

G. Ruan, D. Thakur, S. Hawkins, J. O. Winter, The Ohio State Univ. (United States) 
SESSION 7 APPLICATIONS OF COLLOIDAL NANOPARTICLES IN FLOW CYTOMETRY, CELL LABELING, AND NEUROSCIENCE

$75750 \mathrm{M}$ Quantum-dot-based quantitative identification of pathogens in complex mixture (Invited Paper) [7575-44]

S. H. Lim, Institut Pasteur Korea (Korea, Republic of) and Ctr. for Neglected Diseases Drug Discovery, Institut Pasteur Korea (Korea, Republic of); F. Bestwater, Institut Pasteur Korea (Korea, Republic of); P. Buchy, S. Mardy, Institut Pasteur Cambodia (Cambodia); A. D. C. Yu, Institut Pasteur in Cambodia (Korea, Republic of) and Korean Advanced Institute of Science and Technology (Korea, Republic of)

7575 OP Biocompatible water soluble quantum dots as new biophotonic tools for hematologic cells: applications for flow cell cytometry [7575-24]

R. B. Lira, A. T. de Sales Neto, K. H. G. Carvalho, E. S. Leite, A. G. Brasil, Jr., D. P. L. Azevedo, P. E. Cabral Filho, M. B. Cavalcanti, A. J. Amaral, P. M. A. Farias, B. S. Santos, A. Fontes, Univ. Federal de Pernambuco (Brazil)

\section{SESSION 8 APPLICATIONS OF COLLOIDAL NANOCRYSTALS IN CELL BIOLOGY}

7575 OR In vitro imaging of cells using peptide-conjugated quantum dots (Invited Paper) [7575-46] M. Ishikawa, V. Biju, Health Technology Research Ctr., National Institute of Advanced Industrial Science and Technology (Japan)

7575 OS Delivery of quantum dot bioconjugates to the cellular cytosol: release from the endolysosomal system [7575-26]

J. B. Delehanty III, C. E. Bradburne, K. E. Boeneman, I. L. Medintz, D. Farrell, T. Pons, B. C. Mei, U.S. Naval Research Lab. (United States); J. B. Blanco-Canosa, P. E. Dawson, Scripps Research Institute (United States); H. Mattoussi, U.S. Naval Research Lab. (United States)

7575 OT Cellular uptake of conjugated InP quantum dots [7575-27]

H. Chibli, L. Carlini, K. Ntumba, J. Nadeau, McGill Univ. (Canada)

\section{SESSION 9 APPLICATIONS OF COLLOIDAL QUANTUM DOTS IN CANCER DIAGNOSTICS AND THERAPY}

$75750 Z$ Radiation sensitivity enhancement in cells using high-Z nanoparticles [7575-33]

N. J. Withers, J. B. Plumley, B. A. Akins, A. C. Rivera, G. Medina, G. A. Smolyakov,

G. S. Timmons, M. Osiński, The Univ. of New Mexico (United States) 
757510 Whole-body imaging of HER2/neu-overexpressing tumors using scFv-antibody conjugated quantum dots [7575-34]

I. V. Balalaeva, Nizhny Novgorod State Univ. (Russian Federation) and Institute of Applied Physics RAS (Russian Federation); T. A. Zdobnova, Nizhny Novgorod State Univ. (Russian Federation) and Shemyakin and Ovchinnikov Institute of Bioorganic Chemistry RAS (Russian Federation); A. A. Brilkina, Nizhny Novgorod State Univ. (Russian Federation) and Institute of Applied Physics RAS (Russian Federation); I. M. Krutova, Nizhny Novgorod State Univ. (Russian Federation); O. A. Stremovskiy, E. N. Lebedenko, Shemyakin and Ovchinnikov Institute of Bioorganic Chemistry RAS (Russian Federation); V. V. Vodeneev, Nizhny Novgorod State Univ. (Russian Federation); I. V. Turchin, Institute of Applied Physics RAS (Russian Federation); S. M. Deyev, Shemyakin and Ovchinnikov Institute of Bioorganic Chemistry RAS (Russian Federation)

\section{SESSION 10 CYTOTOXICITY AND APPLICATIONS OF COLLOIDAL QUANTUM DOTS IN DRUG DELIVERY}

757513 Studying nanotoxic effects of CdTe quantum dots in Trypanosoma cruzi [7575-37] C. V. Stahl, Lab. de Transmissores de Leishmanioses, IOC-FIOCRUZ (Brazil); D. B. Almeida, A. A. de Thomaz, Lab. de Aplicações Biomédicas de Lasers, Instituto de Física, UNICAMP (Brazil); A. Fontes, Univ. Federal de Pernambuco (Brazil); R. F. S. Menna-Barreto, Lab. de Biologia Celular, IOC-FIOCRUZ (Brazil); J. R. Santos-Mallet, Lab. de Transmissores de Leishmanioses, IOC-FIOCRUZ (Brazil); C. L. Cesar, Lab. de Aplicações Biomédicas de Lasers, Instituto de Física, UNICAMP (Brazil); S. A. O. Gomes, Lab. de Transmissores de Leishmanioses, IOC-FIOCRUZ (Brazil); D. Feder, Lab. de Biologia de Insetos, Univ. Federal Fluminense (Brazil)

\section{POSTER SESSION}

757514 Re-disperse of aggregated colloidal quantum dots [7575-38]

N. Manabe, S. Hanada, International Clinic Research Ctr., International Medical Ctr. of Japan (Japan) and Japan Association for the Advancement of Medical Equipment (Japan); Y. Futamura, A. Hoshino, International Clinic Research Ctr., International Medical Ctr. of Japan (Japan); T. Adschiri, Institute of Multidisciplinary Research for Advanced Materials, Tohoku Univ. (Japan); K. Yamamoto, International Clinic Research Ctr., International Medical Ctr. of Japan (Japan)

757515 Silver nanoparticle-induced degranulation observed with quantitative phase microscopy [7575-40]

W. Yang, S. Lee, J. Lee, Y. Bae, D. Kim, Gwangju Institute of Science and Technology (Korea, Republic of)

Author Index 


\title{
Conference Committee
}

\author{
Symposium Chairs \\ James G. Fujimoto, Massachusetts Institute of Technology \\ (United States) \\ R. Rox Anderson, Wellman Center for Photomedicine, Massachusetts \\ General Hospital (United States) and Harvard School of Medicine \\ (United States)
}

Program Track Chairs

Paras N. Prasad, University of Buffalo (United States)

Dan. N. Nicolau, The University of Liverpool (United Kingdom)

Conference Chairs

Marek Osiński, The University of New Mexico (United States)

Wolfgang J. Parak, Philipps-University Marburg (Germany)

Thomas M. Jovin, Max-Planck-Institut für biophysikalische Chemie (Germany)

Kenji Yamamoto, International Medical Center of Japan (Japan)

\section{Program Committee}

Antigoni Alexandrou, Ecole Polytechnique (France)

Moungi G. Bawendi, Massachusetts Institute of Technology (United States)

Maxime Dahan, Laboratoire Kastler Brossel (France)

Jesus M. de la Fuente, Universidad de Zaragoza (Spain)

Alexander Eychmüller, Technische Universität Dresden (Germany)

Jennifer A. Hollingsworth, Los Alamos National Laboratory (United States)

Hedi Mattoussi, Florida State University (United States)

Paul Mulvaney, The University of Melbourne (Australia)

Jay L. Nadeau, McGill University (Canada)

Shuming Nie, Emory University (United States)

Sandra J. Rosenthal, Vanderbilt University (United States)

Tania Q. Vu, Oregon Health \& Science University (United States)

Michael S. Wong, Rice University (United States)

Session Chairs

1 Opening Session

Wolfgang J. Parak, Philipps-Universität Marburg (Germany) 
2 Synthesis and Characterization of Colloidal Nanocrystals for Biomedical Applications I

Wolfgang J. Parak, Philipps-Universität Marburg (Germany)

3 Synthesis and Characterization of Colloidal Nanocrystals for Biomedical Applications II

Thierry Gacoin, Ecole Polytechnique (France)

$4 \quad$ Biofunctionalization of Colloidal Nanocrystals

Jay L. Nadeau, McGill University (Canada)

5 Resonant-Energy-Transfer-based Nanosensing and Energy Conversion Jesus Martinez de la Fuente, Universidad de Zaragoza (Spain)

6 Novel Quantum-Dot-based Sensors

Niko Hildebrandt, Fraunhofer Institut für Angewandte Polymerforschung (Germany)

$7 \quad$ Molecular-Level Sensing with Nanoparticles

Shuiqin Zhou, College of Staten Island, City University of New York (United States)

8 Applications of Colloidal Nanoparticles in Flow Cytometry, Cell Labeling, and Neuroscience

Raimund Ober, The University of Texas at Dallas (United States)

9 Applications of Colloidal Nanocrystals in Cell Biology

Marek Osiński, The University of New Mexico (United States)

10 Applications of Colloidal Quantum Dots in Cancer Diagnostics and Therapy

Oliver Bruns, Heinrich-Pette-Institute, Universität Hamburg (Germany)

11 Cytotoxicity and Applications of Colloidal Quantum Dots in Drug Delivery

Kenji Yamamoto, International Medical Center of Japan (Japan)

AWARD Ocean Optics Young Investigator Award Ceremony

Marek Osiński, The University of New Mexico (United States) 